\title{
EXCURSION CONTROL AT IN SITU URANIUM MINES
}

CONF-870211- I

DE87 004061

\author{
W. P. Staub \\ Energy Division \\ Oak Ridge National Laboratory* \\ Oak Ridge, Tennessee 37831
}

\footnotetext{
* Operated by Martin Marietta Energy Systems, Inc., Under Contract No. DE-ACD5-840R21400 with the
U.S. Department of Energy
}

\section{DISCLAIMER}

This report was prepased as an account of work sponsored by an agency of the United States Government. Neither the United States Government nor any agency thereof, nor any of their employees, makes any warranty, express or implied, of assumes any legal liability or responsibility for the accuracy, completeness, or usefulness of any information, apparatus, product, or process disclosed, or represents that its use would not infringe privately owned rights. Reference herein to any specific commescial product, process, or service by trade name, trademark, manufactures, or otherwise does not necessarily constitute or imply its endorsement, recommendation, of favoring by the United States Government of any agency thereof. The views and opinions of authors expressed herein do nol necessarily state or reflect those of the United States Government or any agency thereof. 
William D. Staub,

Oak Ridge National Laboratory, Dak Ridge, Tennessee

\section{INIRODUCTION}

$\therefore \quad$ Intensive research and development of in situ uranium mining took place in the United States during the 1970's. By the end of the decade, nearly 108 of all uranium production came from in situ mines. Recent poor market conditions, however, forced the closure of all domestic in situ uranium mines.

When market conditions improve, domestic in situ mining is expected to make a modest recovery. Successful licensing of future in situ mines will depend to a large extent on the ability to contain the leach solutions (lixiviant) within the ore zone. Uncontrolled movement of lixiviant beyond the ore zone is called an excursion.

Early detection of an excursion is a necessary prelude to the implementation of timely corrective action to return escaping fluid to the well-field. Without timely corrective action, a large quantity of valuable production fluid may be irretrievably lost and serious contanination of adjacent groundwater resources may result.

Tho types of excursion are recognized: horizontal and vertical. In horizontal excursions lixiviant remains strata bound but migrates laterally away fron the production wll-field. In vertical excursions lixiviant escapes into aquifers above or below the ore bearing strata.

In situ mining may not be permitted when monitor wells outside the ore zone are on excursion status. Monitor wells are classified as being on excursion status whenever selected chemical constituents (excursion indicators) exceed given concentrations, referred to as upper control limits (IJCL's).

This paper summarizes excursions based on case histories of 9 in situ uranium mines ( 7 in wyoming and 1 in Texas). These case histories were compiled from data provided by the U.S. Nuclear Regulatory Commission, the Wyoming Department of Environmental 
Quality, and the Texas Department of Water Resources. Most of these data were provided to the above agencies by mining companies in response to regulatory requirements pertaining to licensing actions. Case histories and detailed excursion analyses are presented in Staub et al. [1]

\section{HORIZONTAL EXCURSIONS}

The only serious horizontal excursions described by Staub et al. [1] occurred during the early history of in situ uranium mining. Several intense and long-term excursions took place during experimental pilot tests in the early- to mid-1970's. These excursions were attributed to numerous breakdowns in pumping equipment and failure to adjust injection-production rates in response to these breakdowns. The total volume of fluid injected during these pilot tests exceeded the amount produced, a practice which is now recognized by the industry as a fundamental cause of horizontal excursions.

The in situ mining industry has had a good record of controlling horizontal excursions since the late 1970's. Most recent horizontal excursions have been brought under control within 2 to 5 months of their discovery. The incidence of horizontal excursions is reduced by controlling the field-wide production rate at a few percent greater than the injection rate (known as "bleeding" the ore zone aquifer) and storing the excess fluid in a secure surface impoundment for eventual evaporation. Although bleeding the aquifer prevents field-wide excursions, local excursions occasionally occur. They are controlled by either local or field-wide manipulations of injection and production rates ranging from slightly reduced injection to complete injection well shut-down while continuing to produce from the ore zoise aquifer. The range of options availaible depends on the size of the impoundment for storage of excess production fluid.

\section{VERTICAL EXCURSIONS}

To date, the in situ mining industry has had difficulty in controlling vertical excursions. Serious vertical excursions persisted at several sites through the end of 1981 when commercial scale in situ mining was suspended in response to the declining uranium market. A number of shallow aquifer monitor wells have remained on excursion status for several years.

Many vertical excursions are attributable to broken casings in injection or production wells or improperly abandoned exploration wells. State-of-the-art well completion procedures have virtually eliminated injection and production well failures. Old and abandoned exploration wells remain as major pathways of excursion because they are difficult to locate.

Some vertical excursions may also be responses to leaky aguifer conditions [2]. Too little is known at this time to assess the significance of leaky aquifers relative to that of abandoned wells in causing vertical excursions. 
Vertical excursions may be controlled by repairing ruptured casings in injection and production wells or, alternatively, by abandoning and seal ing them off with cement. Improperly sealed or unsealed exploration holes are located and also sealed off with cenent. Once sealed, these wells cannot be used to recover escaped lixiviant. Restoration of the shallow aquifer may be required, depending on the extent of the excursion. Completely new well-fields would need to be developed for restoration. At present no techniques are available for controlling excursions attributable to leaky aquifer systems.

\section{EVALUATING EXCURSION POTENTIAL}

Although current aquifer testing procedures are often useful in appraising the potential for horizontal excursions, they have had less success in determining the potential for vertical excursions. The short duration of these tests and the small number of wells involved reduces the possibility of measuring observable responses in shallow aquifer monitor wells. Furthermore, such tests reflect only localized rather than field-wide conditions.

To overcome the disadvantages of short-tem aquifer tests a mining unit could be certified by commencing operations but injecting a chemically stable and unretarded tracer instead of lixiviant. Production fluid could be held in surge tanks or an evaporation pond until the test is completer. Shallow monitor wells would be observed for changes in water level and possibly the appearance of tracers. An appropriate duration for certification tests is uncertain at this time. Each time a vertical excursion occurs the mining unit would require recertification.

\section{EXCURSION DETECTION}

Both horizontal and vertical excursions can be more effectively controlled through timely detection. Effective excursion monitoring requires detailed groundwater chemical characterization to define natural variations in water quality. According to Deutsch et al. [3] median and variance in baseline water qual ity can be used to establish upper control limits (UCL's) for given ions based on their low probabilities of natural exceedance.

Proper selection of excursion indicators is critical. Table 1 sumarizes the generalized suitability of various excursion indicators for monitor well observations, sampling and analysis. Same indicators are time dependent. Trace elements, TDS, and $\mathrm{Cl}^{-}$are not concentrated until the lixiviant has circulated several times through the mining unit and ion exchange towers. Other indicators are lixiviant dependent ( $\mathrm{pH}$, alkalinity, and $\mathrm{HCO}_{3}$ ). Any chemical indicator may be unsuitable when its baseline concentration is high and/ or has a broad range in the natural environment or is chemically unstable [3]. Chemically unstable constituents in solution are readily adsorbed on clay minerals or may precipitate if they are sensitive to changes in $\mathrm{pH}$ or oxidizing - reducing conditions. Water level may not be a reliable indicator where it 
Time Dependency

\begin{tabular}{|c|c|c|c|c|c|}
\hline \multirow[b]{3}{*}{ Indicators } & \multirow{3}{*}{$\begin{array}{l}\text { Potential Unique Interfering } \\
\text { Chemical Reactions } \\
\text { or Conditions }\end{array}$} & \\
\hline & & \multicolumn{2}{|c|}{$\begin{array}{l}\text { Initial } \\
\text { Lixiviant }\end{array}$} & \multicolumn{2}{|c|}{$\begin{array}{l}\text { Chemically Stabi- } \\
\text { lized Lixiviant }\end{array}$} \\
\hline & & Acid & Alkaline & Acid & Alkaline \\
\hline TDS & None & & & $\mathrm{x}$ & $\mathrm{x}$ \\
\hline Alkal inity & $\begin{array}{l}\text { Subject to buffering by host rock and } \\
\text { natural groundwater }\end{array}$ & & $x$ & & $\mathrm{x}$ \\
\hline $\mathrm{Cl}^{-}$ & None & & & $\mathrm{x}$ & $\mathrm{x}$ \\
\hline $\mathrm{HCO}_{3}^{-}$ & $\begin{array}{l}\text { Subject to buffering by host rock and } \\
\text { natural groundwater }\end{array}$ & & $\mathrm{x}$ & $\mathrm{x}$ & $\mathrm{x}$ \\
\hline $\mathrm{pH}$ & $\begin{array}{l}\text { Subject to buffering wy host rock and } \\
\text { natural groundwater }\end{array}$ & $x$ & & $\mathrm{x}$ & $x$ \\
\hline $\mathrm{SO}_{4}=$ & $\begin{array}{l}\text { Subject to chemical precipitation as } \\
\text { gypsum }\end{array}$ & $\mathrm{x}$ & & $\mathrm{x}$ & $x$ \\
\hline $\begin{array}{l}\text { Trace Ele- } \\
\text { ments }\end{array}$ & $\begin{array}{l}\text { Subject to chenical precipitation and } \\
\text { adsorption on clay minerals }\end{array}$ & & & $\mathrm{x}$ & $\mathrm{x}$ \\
\hline Water Level & $\begin{array}{l}\text { Subject to external influences such } \\
\text { as mine dewatering and irrigation }\end{array}$ & $x$ & $\mathrm{x}$ & $\mathbf{x}$ & $\mathrm{x}$ \\
\hline
\end{tabular}


is subject to external influences such as mine dewatering, irrigation, and seasonal fluctuation.

Chemical instability is a significant oncern when monitoring for hrizontal excursions. As Figure 1 illustrates, vertical excursions often follow short-circuited pathways through oxidized zones. Hence, most ionic species tend to remain in solution so long as the monitoring well is screened in an oxidizing zone. Conversely, hrizontal excursions often foliow an extended pathway which includes a mineralized wne under natural reducing conditions. Thus, lixiviant escaping laterally along ore-bearing strata is subject to greater buffering, adsorption, and chemical precipitation than is lixiviant escaping through broken casings and abandoned but open exploration holes. Therefore, great care must be exercised in selecting indicators for monitoring horizontal excursions. In view of the above discussion, it is somewhat paradoxical that the in situ mining industry has a better track record in dealing with horizontal, rather than vertical, excursions.

There are two reasons why the industry's history of monitoring for vertical excursions has been less effective than one might expect, based on the above discussion. First, some shallow monitor wells were screened at locations where reducing conditions existed. second, UCL's for trace element indicators were often set inrealistically low.

Monitoring within an aquifer where reducing conditions exist is problematical. Chemical indicators oxidized and solubilized by lixiviant in the ore zone may be reduced and precipitated along the pathway toward the monitor well. Natural concentrations of trace elements are often high where reducing conditions exist.

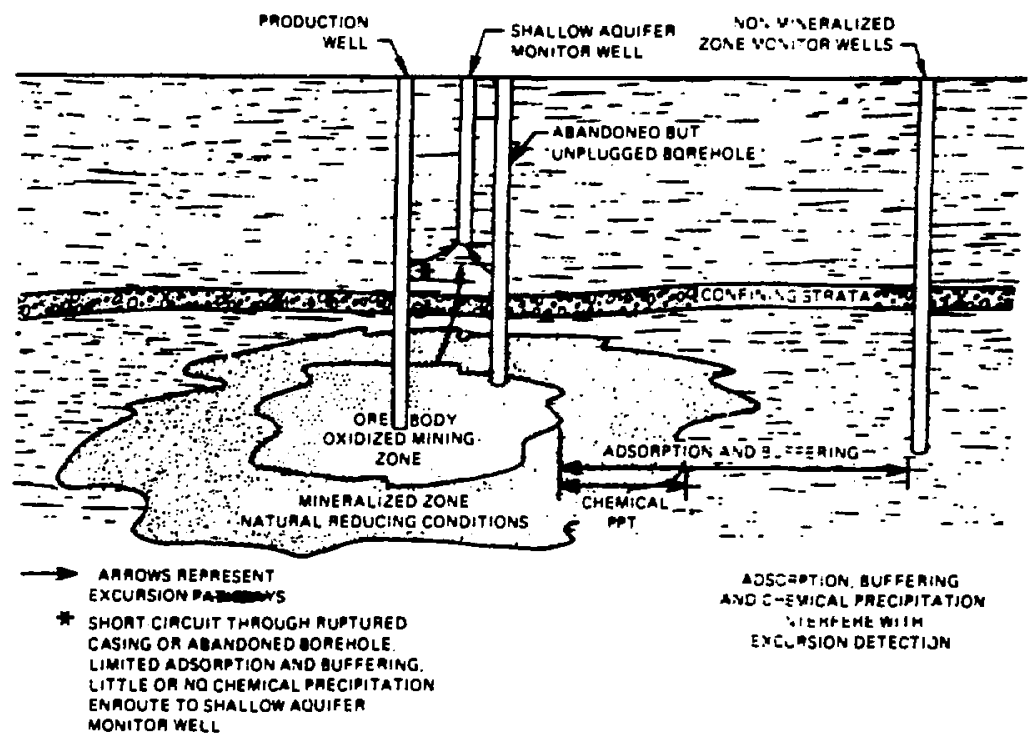

Figure 1. Comparison of pathways for horizontal and vertical excursions. 
Introduction of oxygen during well construction and sampling may solubilize then.

Unrealistically low UCL's for trace elements often led to their abandomment as excursion indicators. The UCL's were typically set at 10 to 208 above baseline concentrations for both oommon ions and trace elements. In a case where the baseline concentration of uranium was $10 \mathrm{ugl}$, its UCL would be only 11 or $12 \mathrm{ugl}$ ( 1 or $2 \mathrm{ugl}$ above background). Because of unrealistically low trace element UCL's, monitor wells screened in a reducing zone often remained on excursion status for extended periods of time. Eventually, it was ascertained that these were not really excursions.

\section{CONCLUSIONS}

Based on the case histories in this study it is believed that the in situ uranium mining industry has demonstrated the ability to reduce and control horizontal excursions. However, the ability to reduce and control vertical excursions has yet to be demonstrated.

Detection of vertical excursions can be improved by screening monitor wells in oxidizing zones and using trace elements (for example uranium, vanadium, arsenic, selenium, and molybdenum) as excursion indicators. To provide reliable indications of an excursion, the UCL's should be set at more practical levels for trace elements, perhaps an order of magnitude above baseline concentrations. Trace elements can be very useful excursion indicators under appropriate conditions and guidelines.

Control of vertical excursions could be improved by mining unit-wide certification using operational mode tests without lixiviant before mining is allowed to commence. Each time a mining unit is placed on excursion status, recertification would be required.

\section{ACKNOWLEDGMENTS}

This research is sponsored by the Nuclear Regulatory Commission, Division of Waste Management, Office of Nuclear Material Safety and Safeguards under contract with Martin Marietta Energy Systems, Inc.

Special recognition is given to R. E. Williams, F. Anastasi, J. Osiensky and D. Rogness of the University of Idaho for compiling the case histories. The author is soleiy responsible for the excursion analysis based on these case histories.

\section{REFERENCES}

1. Staub, พ. P., N. E. Hinkle, R. E. Willians, F. Anastasi, J. Osiensky, and D. Royness. "An Analysis of Excursions at Selected In Situ Uranium Mines in Myoming and Texas," USNRC Report ORNL/TM-9956 (1986). 
2. Lee, D. W. and J. M. Bownds. "Hydrodynamics of Partially Penetrating Wells in a Ieaky Aquifer System," USNRC Technical Letter Report ORNL/NRC LTR-86/14 (1986).

3. Deutsch, พ. J., พ. J. Martin, L. E. Eary, and R. J. Serne. "Methods of Minimizing Ground-Water Contamination from In Situ Leach Uranium Mining," USNRC Peport PNL-5319 (1985). 